\title{
Transitional Justice and Democratic Consolidation in the Post-Communist Space: A Comparative Review of the Czech Republic, Latvia and Slovakia
}

\author{
YERKEBULAN SAIRAMBAY
}

\section{sciendo}

Politics in Central Europe (ISSN: 1801-3422)

Vol. 17, No. 1

DOI: $10.2478 /$ pce-2021-0006

\begin{abstract}
In this comparative review, I first evaluate scholarly findings attempting to dis/prove a relationship between transitional justice and the consolidation of democracy. Second, I outline several criteria for 'democratic' transitional justice in order to be able to judge transitional justice policies. Third, I examine and judge transitional justice policies of the Czech Republic, Latvia and Slovakia by these criteria. Last, I argue that transitional justice is neither a prerequisite for the successful consolidation of democracy nor inherently democratic unless it is carried out in coordination with the ideals of liberal democracy, which might support the achievement of peace and societal stability in a transition period.
\end{abstract}

Keywords: transitional justice, consolidation of democracy, the Czech Republic, Latvia, Slovakia

\section{Introduction}

The skeletons in the closet of post-communist Europe represent many challenges. One such challenge is transitional justice, which addresses the legacies of human rights abuses of the past. Mark Arenhövel (2008: 580) claims that transitional justice is not only a matter of remedying human rights violations, but also is a process that shapes citizens' comprehension of justice and a re/ foundation of democracy. Some people, particularly new policy-makers of 
new regimes, defend transitional justice as a means to consolidate democracy. Citizens' broad participation in the process of designing and implementing transitional justice programmes is found to be of central importance (Arenhövel 2008: 580). As part of post-communist political and economic transitions, various kinds of transitional justice have been applied in Central and Eastern Europe, namely lustration, truth commissions, criminal prosecutions, reparations and various forms of institutional reforms. These phenomena have taken place in the context of democratisation, de-communisation, political and economic transformation, and the process of expanding the European Union. Central and Eastern European transitions to democracy are considered to be part of the third wave of democratisation (popularised by Samuel P. Huntington in 1991), as they share some features that enable them to be distinguished from early transitions. These transitions dealt with the consequences of totalitarianism and collaborators of the past communist rule through means such as transitional justice.

Central and Eastern European countries have applied transitional justice at different levels. The Czech Republic, East Germany (the GDR) and Hungary have implemented widespread and long-lasting lustration, whereas Poland, Romania and Slovakia have instituted insufficient lustration with multiple starts and stops; other countries such as Belarus and Albania can be characterised as non-lustrated (de facto) countries (Horne 2012: 422-423). This variation can be explained by successful/unsuccessful implementation of lustration, the partiality/impartiality of the act and the practicality/impracticality of the framework.

But is transitional justice a prerequisite for the successful consolidation of democracy? It seems to be a problematic question, as it raises tough judicial, political and ethical issues. This article critiques the suggestion of an inter-linkage between transitional justice and consolidation of democracy; however, it asserts that since transitional justice is carried out with the ideals of liberal democracy, transitional justice may assist inceptive democracies as a significant factor in attaining peace and societal stability. Transitional justice is not a requirement and this work refutes the idea that transitional justice is substantially democratic. But by treating the past in an equitable manner, transitional justice can be a moral privilege of liberal democracies. Firstly, this article will evaluate scholarly works attempting to prove/disprove an inter-linkage between transitional justice and the consolidation of democracy. Secondly, some criteria for 'democratic' transitional justice will be set out in order to be able to judge transitional justice policies. Thirdly, it will analyse transitional justice policies in three countries, the Czech Republic, Latvia and Slovakia. Finally, the paper will judge them by the criteria set out for 'democratic' transitional justice. 


\section{Inter-linkage between Transitional Justice and the Consolidation of Democracy}

Proving/disproving relationships between transitional justice and the consolidation of democracy is a complex issue, as it faces many challenges. It is even more difficult to prove inter-linkage, which denotes the idea that transitional justice leads to the successful consolidation of democracy in the context of political and economic transitions. Arenhövel (2008: 570) points out that scholars still lack a complete theory about transitional justice, despite the fact that it is a fast-growing area of academic research, and many try to prove causal links rather than relying on theoretical principles. This research orientation can be caused by a sufficient understanding of the motivations and limitations for reconciliation in greatly fragmented societies. Democratic countries present quite an extensive diversity of ways of dealing with transitional justice. Some countries have been transformed successfully without confrontation with the past (Spain is one clear illustration), while others such as the GDR and the Czech Republic implemented the most immediate and extensive screening (lustration) policies (Letki 2002: 539). These aforementioned countries without doubt are democratic, but they have experienced different transitions and various factors have affected them. Hence, it is empirically impossible to prove a successful consolidation of democracy with only transitional justice.

In spite of the neglect of transitional justice processes, Spain's case, in which all perpetrators have been forgiven and forgotten, is considered a highly democratic result following a dictatorship (Hajji 2014: 84). Can one say that Spain is an undemocratic country? Obviously not, and Spain is not the only Mediterranean state coping with past injustices in such ways. Iosif Kovras (2013: 730) notices that Cyprus's model, as with Spain's, also contradicts the experiences of other countries, such as South Africa, Bosnia and Guatemala, where the focal element of the transition to democracy was truth recovery using transitional justice. These cases demonstrate the practice of peacekeeping and consolidation of democracy without lustration and disprove the direct causal relationship between transitional justice and the successful consolidation of democracy.

Nonetheless, post-communist Europe stands as a better case study than Latin America or South Africa for several reasons. First and foremost, it is a time frame of transitional justice applied in the Central and Eastern European region, from the early 1990s to the early 2000s. Secondly, the heritage of the previous communist system gives a solid understanding of the nature of the transition in Central and Eastern Europe. Thirdly, the geopolitical context of Central and Eastern Europe makes this issue clearer. Fourthly, post-communist countries were not generally socially fragmented. It can be observed by co-operative behaviour of the region's citizens. Finally, the existing literature, which tries to prove 
an inter-linkage of transitional justice and democratisation in post-communist Europe, helps to compare the findings of different scholars. Accordingly, the relationship between transitional justice and the consolidation of democracy can be inferred from [specific regions like] Central and Eastern Europe more easily than in general. Thus, I will discuss the existing scholarly works (findings) which try to prove an inter-linkage between transitional justice and the successful consolidation of democracy in Central and Eastern Europe.

Natalia Letki (2002: 549) asserts that there exists a positive link between transitional justice and the consolidation of democracy in Central and Eastern Europe. In order to assess the extent of lustration she used a holistic approach and classified Central and Eastern European countries as 'lustrated' (the Czech Republic, the GDR, Poland and Hungary) and 'non-lustrated' (Bulgaria, Slovakia, Romania, Albania, Latvia, Estonia and Belarus). Letki also categorised the Czech Republic, the GDR, Poland, Hungary, Estonia, Latvia and Lithuania as more democratic countries with 'advanced democracies' in comparison to Bulgaria, Slovakia and Romania, which had 'liberal democracies'. She based this distinction on the 'combination' of two variables, screening (lustration) and democratic consolidation. However, she failed to explain the disparity between countries with 'advanced democracies'. The actual level of lustration varied among Central and Eastern European countries. For instance, Poland's experience has been characterised by multiple starts and stops to lustration and is described as an 'insufficiently' lustrated country (Horne 2012: 422); whilst the Czech Republic (continuing the policy of Czechoslovakia) applied one of the most comprehensive lustration policies among post-communist European countries in the 1990s (David - Choi 2005: 392-435).

Letki (2002: 548) also claims that countries which have not achieved 'consolidated democracy' are at the same time 'non-lustrated'. However, she does not explain satisfactorily why Latvia and Estonia are 'advanced democracies' and simultaneously 'non-lustrated'. She merely states that 'although limited space does not allow us to investigate these two cases thoroughly, it may be stated that they also experienced a specific purification (...) and Estonian and Latvian problems of dealing with the legacy of the past focused on the Russian minority issue' (Letki 2002: 548). With regard to Lithuania, Letki decided to categorise it as a borderline case and described Lithuania as on the border between 'lustrated' and 'non-lustrated', but with an 'advanced democracy'. Letki (2002: 537) bases her decision on the fact that there were no confrontations with the Lithuanian communists and no negotiations with the Soviet government in Lithuania. Nevertheless, since Letki's research work finished in 1999, implementations of lustration have changed in the Baltic states. Moreover, her work overlooked lustration laws and programmes of all Baltic states (Latvia, Lithuania and Estonia), although some lustration laws were implemented in 1995 and 1999 there (Horne 2012: 423). 
In a journal entitled The International Journal of Transitional Justice, Cynthia Horne (2014) has also questioned whether and how lustration has affected democratisation across 12 countries in the post-communist space. Horne argues that there is a robust relationship between lustration and the consolidation of democracy and the magnitude of this relationship is substantial. She proves this positive inter-linkage using both qualitative and quantitative methods, namely by constructing an original lustration typology to categorise lustration types across twelve Central and Eastern European countries and by applying regression methods to display a consistent and strong relationship between lustration and democracy. Horne's research arrives at three main findings: first, lustration highly supports democratisation; second, lustration, which includes obligatory and wide-ranging bureaucratic change, has greater influence on democratisation than voluntary and minor transitional justice mechanisms; third, there are considerable differences in democracy levels across the lustration categories. These findings are important for this article because in spite of the many contradictory examples of the effects of lustration on societal reconciliation and regime building, the results reflect that lustration may lead to democracy.

Nevertheless, the main weakness of Horne's (2014) study is the failure to draw a distinction between politicisation of transitional justice and the expectation of bureaucratic turnover or renewal. Horne (2014: 503) points out that 'lustration breaks up the patronage networks that existed under the communist system and continue to dominate many areas of economic and political life'. In doing so, her analysis does not take into account that political actors can use lustration as a tool to discredit or remove opponents. This case should be taken into consideration because it can also disrupt the legitimacy of steps towards democracy and menace a democracy's foundation. Furthermore, Horne (2014: 506-507) categorises twelve post-communist countries into four groups: (1) the Czech Republic, Latvia, and Estonia as instances of 'compulsory and wide' lustration; (2) Hungary, Poland, and Lithuania as examples of 'narrow and voluntary' lustration; (3) Bulgaria, Romania, and Slovakia as instances of 'public disclosure and symbolic' lustration; and finally (4) Albania, Russia, and Ukraine as examples of 'no change' lustration countries. Countries such as Russia did not try to apply lustration policies because of the legacies of the past. Only if policy-makers condemned former communist systems can it be said that lustration policies led to trust in public institutions. If the new elite of a hypothetical country has more widespread respect and admiration than the old one, it is more probable that this country can use lustration in its transition. Therefore, I would contest Horne's argument in which she (2014: 517) claims that 'democratic countries do not necessarily choose more extensive lustration or even any lustration at the start of their transitions' with the counter-argument that the Czech Republic and Slovakia did choose very different methods of lustration at the start of their transitions. There was a divergence between 'non-enforcement' 
lustration in Slovakia and 'blitz' lustrations in the Czech Republic (Letki 2002: 545). Thus, the acceptance of lustration also depends on the position of the new elite of a country before and during its transition period. For instance, in the Slovakia's case, the new elite tolerated the communist system and did not allow the implementation of lustration.

Roman David's (2015) experimental analysis of the effects of lustration on trust in governments of Central European countries is research more worthy of attention. David proposes lustration systems (with the regional variant of personnel systems) as a theoretical concept of transitional justice and examines the effects that exposure, dismissal and confession have on trust in governments of the Czech Republic, Poland and Hungary using three main methods of transitional justice: revelation, retribution, and reconciliation. David (2015: 8-9) argues that trust in government, e.g. confidence in its institutional designs, shows that lustration can be positively related to trust in new governments' policies during the democratic transformation. His findings are significant for proving an inter-linkage between transitional justice and democratisation. Lustration increases citizens' trust in a (new) government and its institutions, which contributes to the new regime's legitimacy and the likelihood of its successful consolidation of democracy.

However, David's three-country comparison work concentrates only on the vanguard lustration paths in Central Europe, and consequently restricts the possibility of proving and generalising the causal relationship between democratisation and transitional justice across the entirety of Central and Eastern Europe. As I mentioned earlier, many scholars have categorised transitional justice in the Czech Republic, Hungary and Poland as more lustrated countries compared to other countries in post-communist Europe. Accordingly, in the case of other Central and Eastern European countries, it would not be surprising if transitional justice led to distrust in a given government during its political and economic transformation.

Although there are some scholarly works attempting to prove an inter-linkage between transitional justice and consolidation of democracy in Central and Eastern Europe, these works have not (successfully) proved a causal relationship for several reasons. First of all, there exist normative and methodological challenges and various assumptions that remain empirically under-examined (Snyder - Vinjamuri 2003). Secondly, there is a lack of systematic research on lustration and vetting (Thoms - Ron - Paris 2010). Thirdly, truth commissions are characterised by less consideration for human rights and democracy, and also by the inconclusive effects of trials and amnesties (Olsen - Payne - Reiter 2010). Finally, research on transitional justice and democratisation faces many challenges such as historicism in the context of Central and Eastern Europe. Hence, the different forms of transitional justice like lustration, purges and public access to security files need additional research to prove a relationship between democratisation and transitional justice (Kritz 2009). 


\section{Criteria for 'Democratic' Transitional Justice}

The implementation of transitional justice in Central and Eastern Europe and its role in a transition period is of greater interest to researchers. There are definitely fair and unfair ways of coping with the past. Different methods and analyses of transitional justice and democratisation in Central and Eastern Europe have resulted in mixed outcomes, both positive and negative, dis/proving a causal relationship between the two discussed phenomena. Although there is no completely proven inter-linkage between transitional justice and the consolidation of democracy, I argue that transitional justice may assist incipient democracies as a significant means of achieving peace and societal stability when it is implemented according to several criteria that demonstrate the ideals of liberal democracy. First, policy-makers should have significant control over transitional justice policies. Otherwise, policies might fail or achieve only a fragile democracy or tenuous peace.

Second, only if individual perpetrators are punished by transitional justice forms for offences they have in fact committed, then I argue that transitional justice can be called 'democratic'. O'Donnell et al. (1986) see transitional justice as key to protecting and sustaining new democracies in democratic transitions. This is because past criminals in the new regime can destroy democratic consolidation if they are not lustrated. As reported by the United Nations High Commission on Human Rights in 2006, transitional justice protects against this kind of abuse of power by applying institutional and/or symbolic changes to the residues of the ancien régime (www.ohchr.org). I agree with this argument, but I dispute that individuals should not be lustrated for crimes they have not perpetrated. The use of this practice in Central and Eastern Europe shows that many individuals were punished for collaborating with the Communist Parties or having access to secrets of the parties and for other activities. Therefore, through engagement with the principles of democracy such as respect for the rule of justice and law, lustration of individuals for individual offences perpetrated in the old regime constructs democracy.

Thirdly, in addition to the Universal Declaration of Human Rights and The Charter of the United Nations, transitional justice should be implemented in accordance with international criminal law, international human rights law, international humanitarian law and international refugee law in order that transitional justice be 'democratic' justice. Unless action is taken according to these international laws/standards, transitional justice can risk disrupting or conflicting with criminal accusations, whether these accusations are assumed to be at the national or international levels. Lyal Sunga (2009) asserts that the risk of such disruptions is specifically expressed in situations in which truth commissions use amnesties, and especially in the case of total amnesties to forgive offenders for severe crimes. Consequently, the neglect of international 
standards can lead to the disruption of criminal prosecutions and therefore undermine the consolidation of democracy. Moreover, criminal accusations should be better adapted to place facts/events in the right perspective and to concentrate on victims in order for there to be accountability for past abuses without risking a smooth transition from the old regime to democracy.

Finally, political parties should not use transitional justice as a political instrument to remove or discredit enemies or as a consolidation of their own power. In other words, justice in a liberal democracy should be implemented in a way that avoids a victor's justice, in which political parties carry out justice on their own basis, employing various regulations to judge what is right and/ or wrong for their own benefit. Otherwise, victor's justice could undermine the legitimacy of democracy and threaten its successful consolidation.

\section{'Democratic' Transitional Justice in the Czech Republic, Latvia and Slovakia?}

In this section, I will discuss transitional justice implementations in three Central and Eastern European countries, namely in the Czech Republic, Latvia and Slovakia. These three countries are chosen because all of them currently represent 'high' levels of democracy but implemented quite different transitional justice policies in their transitions to democracy.

\section{The Czech Republic}

Many scholarly works (e.g. Letki 2002: 539; David 2012: 762; Nedelsky 2004: 76; Cabada 2012: 55) mention that between 1990 and 2010 the Czech Republic implemented the most extensive, comprehensive and enduring transitional justice policies among post-communist European countries. The Czech Republic set up the framework for transitional justice in the beginning of its political reforms (1990 to 1993) as part of Czechoslovakia, and when it was dissolved, the independent Czech Republic continued to implement transitional justice using three groups of measures: revelation, retribution, and reparation (David 2012: 764).

Although Czechoslovakia was among the last countries in Central and Eastern European to overthrow communism, it was the first government in the region to enact the lustration law in the region on 4 October 1991. According to this law, the following groups of people, among others, were excluded from public employment: high officials of the Communist Party, members, informers and collaborators of State Secret Police (StB), members of People's Militias, students and researchers of certain high schools (Lustration Law 1991). Bílková (2015: 2) points out that this act, called the Great Lustration Act, is the first one of two lustration acts in Czechoslovakia. The second, the Small Lustration Act, was enacted in June 1992 and designed only for the Czech part of Czechoslo- 
vakia. The Small Lustration Act is very similar to the Great Lustration Act and was 'specifically designed to apply to certain positions within the Ministry of Interior, the Police and the Penitentiary Service' (Bílková 2015: 2). However, both these acts operate in a similar way on the practical level in that they involve a screening of the former regime's people for certain public positions.

Kieran Williams (2003: 21) notices that the Czech Republic lustrated 402,788 of its ten million citizens, and about three per cent of those screened in 1991 and 1995-2000 did not obtain acknowledgment from the advocates of lustration. Nedelsky (2004: 76) also states that 'in 2001, 2.5 percent of the applicants did not receive such confirmation'. Furthermore, it was revealed in 1998 that there was 'a black market in fake certificates claiming that the bearer had not worked for or with the Czech State Security (StB)' in the Czech Republic and 'in 2001, it was reported that errors had been made by the interior ministry in 117 cases' (Williams 2003: 21). In 2002, 'a group of right-wing senators successfully initiated a bill to broaden access to StB archives (including express provision for the identification of informers referred to in reports only by their cover names) and publish the names of around 75,000 informers' (Williams 2003: 21). Williams (2003: 22) further argues that wider access to secret files in Czech Republic does not create 'the moments of confession and redemption that $[. .$.$] have never arisen in the decadelong practice of lustration'. Instead,$ it raises ethical issues as it deals with the information of individuals. Legal scholars and political theorists have often raised debates on the dual role of the Czech Republic's lustration law in relation to violence, particularly Jochnick, Normand, Sarat, Brawn, Halley and Teitel (all authors cited in Leebaw 2008: 97), who argue that 'while law can be a tool for regulating violence and exposing abuses of power, law is also utilised to obfuscate and legitimate abuses of power'. Drawing on these arguments, I argue that transitional justice in the Czech Republic can be described as 'non-democratic' because of its unjust punishment of people for many years.

There were many 'non-democratic' transitional justice measures in the Czech Republic. If someone felt wrongly nominated as a potential lustration target, she or he could ask for re-examination before an appeal committee and by 1994, there had been filed 577 requests for re-examination (Nalepa 2010: 68). However, Monika Nalepa notes that in reality the Constitutional Court cancelled appeals because it seemed the appeals procedure collaborated with these targets. Tucker (2004 cited in Nalepa 2010: 69) contends that the StB files were 'edited' by the secret services in expectation of the fall of communism and therefore were less reliable. Vaclav Havel, president of the Czech and Slovak Federative Republic, was against any instances of revenge or fanaticism and thought that many people could be mistakenly listed in the StB's files or even have no idea 'whether, by accident, [they] might have stepped into something' (Michnik Havel 1993: 22). Although the Czech Republic is indexed as having a high level 
of democracy (Freedom House 2017; 2019), all these facts demonstrate that transitional justice in the Czech Republic was politicised and many innocent individuals were lustrated. These kinds of indicators do not meet the criteria for 'democratic' transitional justice that I listed before.

\section{Latvia}

Lustration (or more widely transitional justice) in the Baltic states is not as well researched as in the Czech Republic and few scholarly works specifically address lustration in the Baltic states. According to Freedom House (2017; 2019), Latvia is indexed as a country with a democratic level as high as that of the Czech Republic. However, the Baltic states' lustration policies represent exceptional features, as Latvia, Estonia and Lithuania were under totalitarian regimes after Soviet occupation and did not have their own politically autonomous institutions. Moreover, Latvia experienced so-called lustration 'with a Latvian flavour' and there was no centralised lustration law apart from 14 different kinds of legal acts; in addition, 'the KGB files have not been made available to the public, and no incentive-based lustration legislation has been adopted' (Zake 2010: 394). Although there was not a centralised lustration law, some people underwent criminal prosecution as informants of the KGB in Latvia. Horne (2014: 507) points out that there was a mixture of lustration and anti-Russian policies in Latvian transitional justice. Ethnic Russians were removed for their participation in the communist party of Latvia and even their descendants were made to answer for their ancestors. Hence, instead of dealing with past injustices, Latvia often used to blame 'colonial Russia' and its descendants.

Generally, Latvian lustration is also considered as an instance of restriction based on employment and political participation. Lustration in Latvia is characterised by evidence-based truth revelation, where someone's collaboration can be proven only when it becomes relevant using accessible information (Zake 2010: 395). This means that when someone runs for a public office or applies for a restricted job position in Latvia, this person's background is checked to show whether she or he was a collaborator. Ieva Zake (2010: 389-412) notes that this investigation is conducted by the Centre for the Documentation of the Consequences of Totalitarianism (TSDC - a state institution charged with guarding and studying the remaining KGB documents). This way of dealing with the past has been broadly challenged and debated by the proponents and opponents of lustration in Latvia. In Latvian lustration most politicians supported the lustration process, whereas intellectuals, namely academics, poets, writers, journalists and other representatives of the intelligentsia were against it and called for a stop to lustration as early as possible (Zake 2010: 389-412). This case shows two non-democratic transitional justice elements in Latvia. First, lustration was politicised and used as a political tool against 'others'. 
Russian minorities, even their descendants, have been unjustly punished by the tyranny of the majority. Second, there was a distrust of the democratisation by the Latvian intelligentsia. Both these elements contradict the ideals of liberal democracy and reveal lustration 'with a Latvian flavour' as a non-democratic transitional justice.

\section{Slovakia}

Slovakia experienced transitional justice both as a part of Czechoslovakia and as an independent country. This country is chosen as a third case study because its transition contains some distinct features. According to Martin Kovanic (2012: 386-394), Slovakia adopted a political silence in terms of transitional justice after the peaceful dissolution of Czechoslovakia, allowing the old elites to maintain some effect in all of the transition steps in Slovakia. He further emphasises that lustration law was not enforced in Slovakia and it expired in 1996. Even in the Czechoslovak time, the federal lustration law was never applied in Slovakia (Nalepa 2010: 193). That is why transitional justice in Slovakia can be considered as an instance of symbolic lustration, which acknowledges unlawful suffering, although there was the federal lustration law. While the Czech Republic implemented so-called 'wild lustration', Slovakia's old and new elite did not allow the use of lustration. Cynthia M. Horne (2014: 506-507) categorises Slovakian lustration as 'public disclosure and symbolic change', whilst Natalia Letki (2002: 549) classifies Slovakia as a 'non-lustrated' country with liberal democracy.

One might ask why there was a lack of political will to impose lustration measures in Slovakia and why the Slovak political elite took this approach despite the fact that the lustration law was a federal act. These questions can be answered by delving into the repression and legitimacy of the communist regime in Slovakia and political opposition to the new regime in the transition period. Compared to the Czech Republic, 'Slovakia had a less negative view of the Communist regime [...] and there was little interest among elites or the public in lustration' (Merryman and Tafel 2009: 10). 'The federal lustration law, as well, "had only a formal effect" in Slovakia' (Darski 1993 cited in Nedelsky 2004: 77). Drawing on the theories of transitional justice in the former Czechoslovakia offered by Huntington (1991), Nedelsky (2004: 80) explains this divergence by stating that the Czech Republic pursued a policy of 'prosecute and punish', while Slovakia chose to 'forgive', if not 'forget' its former officials. Nedelsky argues that the level of repression was higher in the Czech Republic than in Slovakia 'during the last twenty years of the communist regime's existence' (Nedelsky 2004: 80). She (2004: 81) further argues that a lesser level of repression resulted in a higher level of regime legitimacy in Slovakia and 'contributed to a lesser interest in transitional justice there than in the Czech lands'. 
Another sound explanation for why the Slovak political elite did not impose lustration measures is that there was a lack of Slovak opposition to the regime during the transition period. In July 2002, the Parliament of Slovakia passed a law allowing citizens to access secret police files, but the law was overridden by 'a veto by President Rudolf Schuster the following month' (Nedelsky 2004: 79). Although, according to Freedom House $(2017 ; 2019)$, Slovakia along with the Czech Republic and Latvia display a high level of democracy, it is certain that transitional justice policies were not consistent with the ideals of liberal democracy, as the new elite of Slovakia tolerated a communist system politicising transitional justice.

\section{Discussion}

Table 1 below illustrates several characteristics of transitional justice based on various scholarly works (e.g. Horne 2012; Zake 2010; Horne 2014; Nalepa 2010; Kovanic 2012; Letki 2002; Williams 2003). The table shows that some countries of the Soviet bloc, such as the Czech Republic, Latvia and Slovakia, have experienced different transitional justice policies (Table 1). As a result, these experiences led to different non-democratic transitional justice with violations of human rights and victor's justice in all three countries. However, the countries have consolidated democracy without any doubt and show a high level of democracy nowadays. My comparative case study results show that translational justice was not a prerequisite for the successful consolidation of democracy.

\section{Table 1: Comparison of Transitional Justice and Democratic Consolidation}

\begin{tabular}{|c|c|c|c|}
\hline Characteristics & The Czech Republic & Latvia & Slovakia \\
\hline Transitional Justice & $\begin{array}{l}\text { widespread and } \\
\text { long-lasting }\end{array}$ & $\begin{array}{l}\text { with a 'Latvian } \\
\text { flavour' }\end{array}$ & $\begin{array}{l}\text { insufficient/ } \\
\text { symbolic }\end{array}$ \\
\hline Lustration Law & $\begin{array}{l}\text { adopted and } \\
\text { implemented }\end{array}$ & $\begin{array}{c}\text { was not adopted; only } \\
14 \text { different kinds of } \\
\text { legal acts }\end{array}$ & $\begin{array}{l}\text { adopted, but was not } \\
\text { implemented and } \\
\text { expired in } 1996\end{array}$ \\
\hline $\begin{array}{l}\text { Unjust Punishment of } \\
\text { Innocent Individuals }\end{array}$ & yes & yes & not applicable \\
\hline $\begin{array}{c}\text { 'Democratic' } \\
\text { Transitional Justice? }\end{array}$ & $\begin{array}{l}\text { non-democratic: } \\
\text { (1) politicised; } \\
\text { (2) black market } \\
\text { of fake certificates }\end{array}$ & $\begin{array}{l}\text { non-democratic: } \\
\text { (1) politicised; } \\
\text { (2) against 'others' } \\
\text { (Russians); } \\
\text { (3) distrust by } \\
\text { intelligentsia }\end{array}$ & $\begin{array}{l}\text { non-democratic: } \\
\text { (1) politicised } \\
\text { by new elite }\end{array}$ \\
\hline $\begin{array}{c}\text { Contemporary Level of } \\
\text { Democracy }\end{array}$ & high & high & high \\
\hline
\end{tabular}

Source: Own design based on scholarly works 
If some countries, such as Slovakia, have consolidated democracy without any transitional justice, then we may doubt transitional justice's role as a prerequisite for the successful consolidation of democracy. Furthermore, non-democratic transitional justice may lead to unjust punishments of innocent people, become a political tool and/or can even result in political cleavages. To be a prerequisite for the consolidation of democracy, transitional justice should be applied in accordance with democratic criteria.

The comparison of transitional justice policies and their legal frameworks in the Czech Republic, Latvia and Slovakia indicates that transitional justice in these countries led to 'non-democratic' approaches and outcomes, despite all of them being high democratic countries these days. Without comparative analysis, which can work as a litmus test, it would be highly complicated to argue that transitional justice is not a prerequisite for the successful consolidation of democracy. I recognise that this comparative review deals with a small number of countries in the Central and Eastern European region, thus leaving more space for further research. This research could be extended by conducting comparative analyses outside of the post-communist space, for example, among Latin American countries. This would not only provide us with a better understanding of whether transitional justice is a prerequisite for the successful consolidation of democracy outside of Central and Eastern Europe, but would also give further depth to the comparison between the regions. Eventually, such comparison would allow scholars to make broader and more detailed conclusions regarding the consolidation of democracy through transitional justice.

\section{Conclusions}

In this paper, I evaluated various scholarly works, data and approaches to transitional justice in the Czech Republic, Latvia and Slovakia to examine whether transitional justice policies implemented in these three countries can be called a prerequisite for the successful consolidation of democracy. To strengthen this analysis, I also outlined some criteria for 'democratic' transitional justice that can be distinguished from 'non-democratic' transitional justice.

However, it should be noted that it is problematic to prove an inter-linkage between transitional justice and the successful consolidation of democracy, as it deals with injustices of the past. Therefore, the question as to what extent transitional justice can be a prerequisite for the successful consolidation of democracy is problematic too. If the given question asks to what extent transitional justice is a required stage or part in democratisation, then the answer is 'not to a great extent'. My investigation of the Czech Republic, Latvia and Slovakia indicates that there is no unique system of transitional justice that serves as a necessary prerequisite for the successful consolidation of democracy. The implementation of transitional justice is too country - and context - specific and a dis/proof 
of a causal relationship depends on what kind of transitional justice policies were used and whether they were non/democratic transitional justice. Some countries have implemented widespread blitz or wild transitional justice policies and successfully consolidated democracy, and some have forgiven and forgotten their torturers and successfully become democratic too, while other countries despite many attempts to use transitional justice have still not fully consolidated democracy. When it comes to Central and Eastern European countries, transitional justice seems more a way of dealing with communist traitors rather than a prerequisite for the successful consolidation of democracy. I argue that transitional justice is not inherently democratic, but it can be a moral privilege of liberal democracies to cope with authoritarian crimes against humanity in an equitable manner.

Transitional justice can be a prerequisite for the consolidation of liberal democracy if it is conducted in accordance with the ideals of liberal democracy. Thus, transitional justice may support incipient democracies as an important means of achieving justice, peace, trust and societal stability in a transition period. Moreover, countries ought to deal with their past impartially, avoiding victor's justice.

\section{Acknowledgements}

I would like to take this opportunity to express my sincere gratitude to one anonymous reviewer (P. W. N.) from the University of Cambridge and to anonymous reviewers of 'Politics in Central Europe' Journal for their time, insightful comments and challenging questions that helped to shape this article. I gratefully acknowledge the European Commission's IMRCEES funded programme in studying and writing this paper. I would also like to thank Mr. Nathaniel Skylar Dolton-Thornton (Universities of Cambridge and Oxford) for proofreading the article.

\section{References}

Arenhövel, Mark (2008): Democratization and Transitional Justice. Democratization 15 (3): 570-587.

Bílková, Veronika (2015): Lustration: The Experience of Czechoslovakia/the Czech Republic, report of the conference on "Past and Present-Day Lustration: Similarities, Differences, Applicable Standards", Prague, Czech Republic, 7 September.

Cabada, Ladislav (2012): Anti-Communism in Czech Society and Politics after 1989: Analysis of the Background and Development of the Phenomenon. Journal of East European and Asian Studies 3 (1): 55-75. 
David, Roman - Choi, Susanne Yuk-ping (2005): Victims on Transitional Justice: Lessons from the Reparation of Human Rights Abuses in the Czech Republic. Human Rights Quarterly 27 (2): 392-435.

David, Roman (2012): Twenty Years of Transitional Justice in the Czech Lands. Europe-Asia Studies 64 (4): 761-784.

David, Roman (2015): Lustration and Transitional Justice: Personnel Systems in the Czech Republic, Hungary, and Poland. Philadelphia: University of Pennsylvania Press.

Freedom House (2017): Populists and Autocrats: The Dual Threat to Global Democracy: available at https://freedomhouse.org/report/freedom-world/freedom-world-2017 (27 August 2020).

Freedom House (2019): Democracy in Retreat: available at https://freedomhouse.org/report/ freedom-world/freedom-world-2019 (27 August 2020).

Hajji, Nadia (2014): Post-Transitional Justice in Spain: Passing the Historic Memory Law. Journal of Politics \& Society 25: 83-100.

Horne, Cynthia M. (2012): Assessing the Impact of Lustration on Trust in Public Institutions and National Government in Central and Eastern Europe. Comparative Political Studies 45 (4): 412-446.

Horne, Cynthia M. (2014): The Impact of Lustration on Democratization in Postcommunist Countries. The International Journal of Transitional Justice 8 (3): 496-521.

Huntington, Samuel P. (1991): The Third Wave: Democratization in the Late Twentieth Century. Norman and London: University of Oklahoma Press.

Kovanic, Martin (2012): Transitional Justice Dynamics in Slovakia: From Silence to the Nation's Memory Institute. CEU Political Science Journal 7 (4): 385-410.

Kovras, losif (2013): Explaining Prolonged Silences in Transitional Justice: The Disappeared in Cyprus and Spain. Comparative Political Studies 46 (6): 730-756.

Kritz, Neil. J. (2009): Policy Implications of Empirical Research on Transitional Justice, in: Merwe Hugo Van Der - Baxter, Victoria - Chapman, Audrey R., eds., Assessing the Impact of Transitional Justice: Challenges for Empirical Research. Washington DC: US Institute of Peace Press, 13-22.

Leebaw, Bronwyn A. (2008): The Irreconcilable Goals of Transitional Justice. Human Rights Quarterly 30(1): 95-118.

Letki, Natalia (2002): Lustration and Democratisation in East-Central Europe. Europe-Asia Studies 54 (4): 529-552.

Lustration Law (1991): Zákon, Ktorým sa Ustanovujú Niektoré Ďalšie Predpoklady na Výkon Niektorých Funkcií v Štátnych Orgánoch a Organizáciách Českej a Slovenskej Federatívnej Republiky, Českej Republiky a Slovenskej Republiky. (Act on Lustration) 451/1991.

Merryman, David - Tafel, Heather (2009): History in the Hands of the Politicians: Lustration, Civil Society, and Unfinished Revolutions in Poland, Hungary, Slovakia, and the Czech Republic. Student Summer Scholars 27, 1-24.

Michnik, Adam - Havel, Václav (1993) Justice or Revenge? Journal of Democracy 4 (1): 20-27. 
Nalepa, Monika (2010): Skeletons in the Closet: Transitional Justice in Post-Communist Europe. Cambridge: Cambridge University Press.

Nedelsky, Nadya (2004): Divergent Responses to a Common past: Transitional Justice in the Czech Republic and Slovakia. Theory and Society 33 (1): 65-115.

O'Donnell, Guillermo A. - Schmitter, Philippe C. - Whitehead, Laurence (1986): Transitions from Authoritarian Rule. Baltimore, Maryland: Johns Hopkins University Press.

Office of the United Nations High Commission on Human Rights' website, (2006): available at www.ohchr.org/Documents/Publications/RuleoflawVettingen.pdf (27 August 2020).

Olsen, Tricia D. - Payne, Leigh A. - Reiter, Andrew G. (2010): Transitional Justice in Balance: Comparing Processes, Weighing Efficacy. Washington, DC: US Institute of Peace Press.

Snyder, Jack - Vinjamuri, Leslie J. (2003) Trials and Errors: Principle and Pragmatism in Strategies of International Justice. International Security 28 (3): 5-44.

Sunga, Lyal S. (2009): Ten Principles for Reconciling Truth Commissions and Criminal Prosecutions, in: Doria José - Gasser, Hans-Peter - Bassiouni, Cherif M., eds., The Legal Regime of the International Criminal Court: Essays in Honour of Professor Igor Blishchenko. Leiden - Boston: Martinus Nijhoff Publishers, 1071-1104.

Thoms, Oskar N. T. - Ron, James - Paris, Roland (2010): State-Level Effects of Transitional Justice: What Do We Know? The International Journal of Transitional Justice 4 (3): 329-354.

Williams, Kieran (2003): Lustration as the Securitization of Democracy in Czechoslovakia and the Czech Republic. Journal of Communist Studies and Transition Politics 19 (4): 1-24.

Zake, leva (2010): Politicians Versus Intellectuals in the Lustration Debates in Transitional Latvia. Journal of Communist Studies and Transition Politics 26 (3): 389-412.

Yerkebulan Sairambay is a, Ph.D. student at the Department of Sociology, University of Cambridge/United Kingdom. E-mail: YS500@cam.ac.uk; ORCID: 00000003-2836-4765. 